\title{
Detecção de um Isolado de Grapevine virus A e Caracterização do Gene da Proteína Capsidial
}

\author{
Thor V. M. Fajardo ${ }^{1}$, Osmar Nickel', Marcelo Eiras ${ }^{2}$ \& Gilmar B. Kuhn' \\ ${ }^{1}$ Embrapa Uva e Vinho, Cx. Postal 130, CEP 95700-000, Bento Gonçalves, RS, e-mail: thor@ cnpuv.embrapa.br; ${ }^{2}$ Centro de \\ Sanidade Vegetal, Instituto Biológico de São Paulo, Av. Conselheiro Rodrigues Alves, 1252, CEP 04014-002, São Paulo, SP
}

(Aceito para publicação em 22/07/2003)

Autor para correspondência: Thor V.M. Fajardo

FAJARDO, T.V.M., NICKEL, O., EIRAS, M. \& KUHN, G.B. Detecção de um isolado de Grapevine virus A e caracterização do gene da proteína capsidial. Fitopatologia Brasileira 28:521-527. 2003.

\section{RESUMO}

O Grapevine virus A(GVA) está associado à "Acanaladura do lenho de Kober", uma doença do complexo rugoso da videira (Vitis spp.). Neste trabalho, um isolado brasileiro de GVA (GVARS) foi caracterizado biologicamente por transmissão mecânica para cinco hospedeiras herbáceas e por enxertia na videira indicadora cv. Kober 5BB, e também por sorologia. O RNA total foi extraído de videira infetada cv. Pirovano 65. Para a RT-PCR, dois pares de oligonucleotídeos foram utilizados. Dois fragmentos de DNA, 430 e 451 pb, apresentando sobreposição parcial de nucleotídeos, foram amplificados por PCR. A seqüência do gene da proteína capsidial do GVA-RS com 597 nucleotídeos e 198 aminoácidos deduzidos, com massa molecular calculada de 21,6 $\mathrm{kDa}$, foi alinhada a outros isolados virais. As seqüências de nucleotídeos e aminoácidos deduzidos do GVA-RS apresentaram maior identidade, $91,4 \%$ e $95,4 \%$, respectivamente, com um is olado italiano. O GVA-RS apresentou expressiva divergência dos Vitivirus Heracleum latent virus (HLV), Grapevine virus B (GVB) e Grapevine virus $D(\mathrm{GVD})$, com identidade de nucleotídeos variando de $76 \%$ a $83,1 \%$.

Palavras-chave adicionais: videira, Vitis, GVA, Vitivirus.

\section{ABSTRACT}

Detection and coat protein gene characterization of an isolate of Grapevine virus A

The Grapevine virus A (GVA) is associated with the Kober stem grooving disease, which is part of the grapevine (Vitis spp.) rugose wood complex. In this work, a Brazilian isolate of GVA (GVA-RS) was characterized biologically by mechanical transmission to five herbaceous hosts, by grafting on Kober 5BB grapevine indicator and by serology. Total RNA was extracted from infected grapevine cv Pirovano 65. For a reverse transcribed polymerase chain reaction, two sets of primers were used, resulting in two partially overlapping DNA fragments of 430 and 451 base pairs. The coat protein gene sequence of GVA-RS with 597 nucleotides and 198 deduced amino acids with a predicted $\mathrm{Mr}$ of $21.6 \mathrm{kDa}$, was aligned with those of other viral isolates. The nucleotide and the amino acid sequences of GVA-RS were closest in identity to an Italian isolate, $91.4 \%$ and $95.4 \%$, respectively. The GVA-RS exhibited a strong divergence to the vitiviruses Vitivirus Heracleum latent virus (HLV), Grapevine virus B(GVB) and Grapevine virus $D(\mathrm{GVD})$, displaying nucleotide identity of $76 \%$ $-83.1 \%$.

\section{INTRODUÇÃO}

O lenho rugoso da videira ("Grapevine rugose wood"), que ocorre em vinhedos dos Estados de Pernambuco, Rio Grande do Sul, São Paulo e em vários países vitícolas, é um complexo de quatro doenças causadoras de alterações no lenho de plantas infetadas, do qual faz parte a virose Acanaladura do lenho de Kober ("Kober stem grooving”) (Kuhn et al., 2000; Kuniyuki, 2001).

A acanaladura do lenho de Kober tem etiologia atribuída ao vírus A da videira (Grapevine virus A, GVA), espécie-tipo do gênero Vitivirus (Garau et al., 1994; Regenmortel et al., 2000). Este vírus possui partículas alongadas e flexuosas medindo 725-825 x $12 \mathrm{~nm}$ e genoma de RNA fita simples e senso positivo com aproximadamente 7.400 nucleotídeos. O genoma viral já foi seqüenciado (Minafra et al., 1994; Minafra et al., 1997; Martelli et al., 1997).
O GVA é transmitido mecanicamente, de forma experimental e com dificuldade, para algumas hospedeiras herbáceas (Monette et al., 1990). Tal dificuldade, pode advir do fato de o GVA ter s ua localização restrita ao floema em sua hospedeira natural, a videira (Vitis spp.) (Martelli et al., 1997). A transmissão do GVA também ocorre pela enxertia e a dispersão do vírus por meio de material propagativo infetado. Não se tem relato da transmissão de GVA de uma videira a outra por meio de ferramentas.

O GVA pode ser transmitido de maneira semipersistente por várias espécies de cochonilhas da família Pseudococcidade (Pseudococcus longispinus Targioni Tozzetti, P. affinis Maskell, Planococcus citri Risso e P. ficus Signoret), havendo ainda relato de transmissão por Coccidae (Neopulvinaria innumerabilis Rathvon) (Rosciglione et al., 1983; La Notte et al., 1997; Regenmortel et al., 2000).

Boscia et al. (1992) determinaram a incidência de GVA 
em 1.100 videiras, provenientes de coleções de cultivares, mantidas em campo e com diferentes origens geográficas. O GVA foi detectadoem $20 \%$ das amostras, com grande variação de incidência entre as origens geográficas. Albânia e Malta apresentaram as maiores incidências, 61 e 58\%, respectivamente, enquanto que a menor foi relatada no Magreb, norte da África (12,5\%). Acessos de videiras italianas apresentaram média de infecção por GVA de cerca de 30\%. O GVA foi detectado em $50 \%$ dos 22 acessos de videiras avaliados na Tunísia por Agran et al. (1990).

No Brasil, Kuhn et al. (2002) analisaram a infecção por GVA em 220 amostras de videiras americanas (Vitis labrusca L.), provenientes de municípios da principal região vitícola do Rio Grande do Sul, e encontraram níveis de infecção de 6,1 a $8,6 \%$. Kuniyuki et al. (2001) também detectaram a presença de GVA em videiras infetadas com a Acanaladura do lenho de Kober no Estado de São Paulo.

As acanaladuras podem ser observadas sob a casca do tronco da videira suscetível, na superfície do lenho, e correspondem ao local onde a casca penetra no tronco, formando canaletas de tamanho variado, e prejudicando a formação dos vasos condutores da seiva (Kuniyuki, 2001). As folhas das cultivares tintas podem apresentar avermelhamento em função da formação anormal dos vasos condutores.

A cv. Kober 5BB, um porta-enxerto comercialmente usado em viticultura, é também uma indicadora biológica de infecção por GVA. Na presença deste vírus, inoculado por meio de enxertia da cv. testada sobre a cv. Kober 5BB, esta reage expressando acanaladuras no lenho, e nomeia a virose (Garau et al., 1994). Em algumas cultivares comerciais de videira, a infecção por GVA pode ser latente.

Em videiras afetadas, podem ser observados diminuição do vigor da planta e atraso na brotação das gemas. Nas combinações produtora/porta-enxerto mais sensíveis, a doença pode causar o declínio da planta, que sempre é acompanhado de uma progressiva redução da colheita até a improdutividade total da planta, podendo levá-la a morte (Kuniyuki, 2001).

Os objetivos deste trabalho foram determinar a ocorrência de GVA em vinhedos do Estado do Rio Grande do Sul, caracterizar biológica e sorologicamente um isolado local de GVA, além de caracterizar molecularmente o gene da proteína capsidial deste isolado.

\section{MATERIAL E MÉTODOS}

\section{Isolado viral}

O isolado de GVA, denominado GVA-RS, utilizado neste trabalho foi detectado em videiras da cv. Pirovano 65 (= cv. Italia), obtidas em vinhedo comercial da região de Bento Gonçalves (RS) e mantidas em estufins, enxertadas nas cvs. de porta-enxertos Rupestris du Lot e 420A.

\section{Indexagem biológica}

Para a detecção biológica do GVA, associado às cultivares de videiras avaliadas, foi realizada a indexagem por enxertia de mesa, do tipo ômega, no período de repouso vegetativo das plantas, empregando-se a cv. Kober 5BB como indicadora da acanaladura do lenho. As amostras analisadas consistiram de material vegetativo, a maioria obtida em vinhedos comerciais da Serra Gaúcha. Foram realizadas 29 enxertias, testando-se as seguintes cultivares produtoras: Cabernet Franc, Cabernet Sauvignon, Pirovano 65, Petit Syrah, Red Globe, Tannat e os porta-enxertos 3309, P1103 e SO4. Após as enxertias, as plantas permaneceram em casa de vegetação até a avaliação final, realizada após 24 meses.

\section{Inoculação mecânica em hospedeiras herbáceas}

O isolado GVA-RS foi inoculado mecanicamente pela trituração de pequenos fragmentos do lenho de videiras infetadas (cv. Pirovano 65) em tampão fosfato de potássio 50 $\mathrm{mM} \mathrm{pH} \mathrm{7,5,} \mathrm{contendo} \mathrm{2,5 \%} \mathrm{de} \mathrm{nicotina.} \mathrm{As} \mathrm{folhas} \mathrm{de} \mathrm{Nicotiana}$ occidentalis Wheeler, N. occidentalis Wheelerspp. obliqua, N. megalosiphon Huerck \& Muell., N. benthamiana Domin., N. cavicola N.T. Burb, Chenopodium quinoa Willd. e $C$. amaranticolor Coste et Reyn., polvilhadas com carborundum, foram inoculadas duas vezes. Após três semanas, a expressão dos sintomas foi avaliada visualmente e a presença do GVA confirmada por ELISA e/ou PCR.

\section{ELISA}

Foram analisados nervuras e pecíolos de folhas da base de ramos de videira, coletadas em vinhedos ou casa de vegetação, de janeiro a abril, correspondendo ao período do início da maturação da uva ao início da fase de senescência da cultura no Sul do país. As amostras foram trituradas em nitrogênio líquido e diluídas 1:3 (p/v) em tampão Tris 0,5 M, $\mathrm{pH} 8,2, \mathrm{NaCl}$ a 0,8\% (p/v), PVP 40000 a 2\% (p/v), PEG 6000 a $1 \%(\mathrm{p} / \mathrm{v})$ e Tween 20 a $0,05 \%$ (v/v). As 678 amostras analisadas, de várias cultivares de porta-enxertos e produtoras ( $V$. vinifera L. e V. labrusca L.), foram provenientes de diversos vinhedos comerciais, a maioria de municípios da Serra Gaúcha (Antônio Prado, Bento Gonçalves, Caxias do Sul, Dois Lajeados, Farroupilha, Feliz, Flores da Cunha, Garibaldi, Monte Belo do Sul, Nova Pádua, Nova Prata, Nova Roma do Sul, Pinto Bandeira, São Marcos e Veranópolis).

O DAS-ELISA (Clark \& Adams, 1977) foi conduzido com anti-soros comerciais contra o GVA, seguindo-se as recomendações dos fabricantes (Biorad/Sanofi, França e Agritest, Itália). Com o anti-soro italiano, procedeu-se à précobertura das placas com proteína A, seguindo-se as etapas de adição do anticorpo policlonal, da amostra e do anticorpo monoclonal ligado à fosfatase alcalina (Boscia et al., 1992). Os extratos foliares das hospedeiras herbáceas inoculadas com GVA foram submetidos ao teste ELISA com os seguintes anti-soros (AS): ELISA direto com AS contra GVA e Grapevine virus B (GVB) (Agritest) e ELISA indireto com AS contra GVA e Grapevine virus D (GVD) (cedidos pelo Dr. A. Minafra, Bari-Itália), definindo-se como infetadas, as amostras cuja absorbância era, no mínimo, duas vezes superior à verificada nas amostras sadias. 
Detecção e caracterização do gene da proteína capsidial de um...

\section{Extração de RNA total}

A extração de RNA total, a partir de $100 \mathrm{mg}$ de nervuras e pecíolos de folhas ou de fragmentos do lenho de videiras cv. Pirovano 65 infetadas com GVA, além de tecido foliar de hospedeiras herbáceas inoculadas, foi realizada utilizando-se o "RNeasy Plant Mini Kit" (Qiagen), com pequenas modificações. O tecido vegetal foi triturado em nitrogênio líquido, adicionando-se a seguir $450 \mu \mathrm{l}$ do tampão de extração de MacKenzie et al. (1997) e incubandose a amostra por $3 \mathrm{~min}$ a $56^{\circ} \mathrm{C}$. As etapas s eguintes foram desenvolvidas conforme as recomendações do fabricante.

\section{Síntese do cDNA, RT-PCR e clonagem}

Procedeu-se a síntese do cDNA viral conforme descrito por Fajardo et al. (2000). Foram empregados dois pares de oligonucleotídeos para a amplificação do GVA-RS: C995: 5'AAGCCTGACCTAGTCATCTTGG3' (complementar) e H587: 5'GACAAATGGCACACTACG3' (viral), além do C1197: 5'TACCCGTGAGAAATG ATGGG3' (complementar) e 766: 5'GGGGAGGTAGATATAGTAGG3' (viral) (Minafra et al., 1992; Minafra \& Hadidi, 1994). As reações da PCR foram preparadas conforme já publicado (Fajardo et al., 2000). Após aquecimento a $94{ }^{\circ} \mathrm{C}$ por $5 \mathrm{~min}$, seguiram-se 35 ciclos de amplificação, compostos de desnaturação $\left(94{ }^{\circ} \mathrm{C} / 45 \mathrm{seg}\right)$, pareamento $\left(48^{\circ} \mathrm{C} / 45 \mathrm{seg}\right)$ e extensão $\left(72^{\circ} \mathrm{C} / 45 \mathrm{seg}\right)$, com uma extensão final a $72{ }^{\circ} \mathrm{C} / 7 \mathrm{~min}$.

O produto da amplificação foi analisado em gel de agarose 1,5\%, preparado em tampão TBE, $\mathrm{pH} 8,0$. As bandas, com os fragmentos de DNA de tamanho esperado, foram extraídas do gel e o DNA foi eluído utilizando-se o "GFX PCR DNA and Gel Band Purification Kit" (Amersham Biosciences), de acordo com as especificações do fabricante.

Os dois fragmentos de DNA amplificados, específicos para o GVA-RS, também foram clonados, em vetor pGEM-T Easy (Promega) e Escherichia coli JM109, conforme descrito em Fajardo et al. (2000).

\section{Seqüenciamento e estudo de homologia de seqüências}

Os fragmentos de DNA eluídos foram precipitados a frio com etanol absoluto e acetato de sódio $3 \mathrm{M}, \mathrm{pH}$ 5,1. Os sedimentos obtidos, por centrifugação, foram ressuspendidos em TE pH 8,0 e purificados em coluna Qiaquick (Qiagen) para o sequienciamento automático de nucleotídeos. Foram realizadas quatro reações de seqüenciamento com cada oligonucleotídeo para a confirmação da seqüência.

As seqüências de nucleotídeos e de aminoácidos deduzidos foram analisadas e comparadas às seqüências existentes no banco de dados GenBank, utilizando-se o programa BLAST do "National Center for Biotechnology Information" (NCBI) (www.ncbi.nlm.nih.gov). Foram elaborados dendrogramas, utilizando-se o software TreeView 1.5 (Page, 1996), obtido através do alinhamento (Clustal X) das sequiências de nucleotídeos e de aminoácidos deduzidos do gene da proteína capsidial do GVA-RS, com outros isolados de GVA e diferentes isolados virais do gênero Vitivirus.

\section{RESULTADOS}

\section{Indexagem biológica}

Três das 29 plantas inoculadas (10,3\%), correspondendo às cvs. Cabernet Franc e C. Sauvignon, manifestaram a presença de acanaladuras no lenho de Kober 5BB após a última avaliação visual.

\section{Infecção em hospedeiras herbáceas}

Nicotiana occidentalis e $N$. megalosiphon, inoculadas com GVA, apresentaram severa deformação, pequenos pontos necróticos e mosqueado nas folhas, além de subdesenvolvimento generalizado da planta. Posteriormente, $N$. occidentalis apresentou necrose das nervuras principais. Chenopodium quinoa apresentou nítidas lesões cloróticas nos bordos das folhas e Nicotiana benthamiana exibiu suave mosqueado foliar. N. occidentalis spp. obliqua, N. cavicola $C$. amaranticolor não exibiram nenhum sintoma.

Independentemente da expressão de sintomas, as seguintes espécies apresentaram resultados positivos de infecção por GVA, após a avaliação por ELISA e/ou PCR: $N$. occidentalis, N. occidentalis spp. obliqua, N. megalosiphon, $N$. benthamiana e C. quinoa. Nenhuma das hospedeiras herbáceas inoculadas apresentou reação positiva com antisoros contra GVB e GVD.

\section{ELISA}

Trinta e uma das 678 amostras analisadas $(4,6 \%)$ estavam infetadas com GVA, destacando-se as cvs. Bordô, Cabernet Sauvignon, Concord, "Franciscana", Gewürztraminer, Goethe, Nebbiolo, Niagara e Tardia de Caxias, e os porta-enxertos IAC 572 e Solferino.

\section{RT-PCR}

Com os pares de oligonucleotídeos H587/C995 e 766/ C1197 foram amplificados fragmentos de DNA de 430 e 451 $\mathrm{pb}$, respectivamente, ambos localizados no gene da proteína capsidial do GVA (Figura 1). As amplificações foram obtidas de videiras cv. Pirovano 65 e de hospedeiras herbáceas infetadas ( $N$. bentamiana e $C$. quinoa) com o GVA-RS.

\section{Alinhamento e comparação das seqüências de nucleotídeos e aminoácidos deduzidos do GVA-RS}

$\mathrm{O}$ alinhamento das seqüências dos dois fragmentos amplificados revelou haver uma sobreposição de 251 nucleotídeos entre os terminais 3' e 5', dos fragmentos de 430 e 451 $\mathrm{pb}$, respectivamente, resultando em uma sequiência de 630 pb. Esta seqüência, em relação à sequiência do isolado italiano de GVA (Is151) (código no GenBank X75433) (Minafra et al., 1994; Minafra et al., 1997), está localizada entre os nucleotídeos 6409-7038. A ORF 4, da proteína capsidial, localiza-se entre os nucleotídeos 6414-7010. A seqüência de 630 pb, obtida neste trabalho, contém a seqüência completa do gene da proteína capsidial do GVA, isolado RS, com 597 pb, codificando 198 aminoácidos deduzidos (Figura 2) com massa molecular calculada de $21,6 \mathrm{kDa}$. A seqüência da proteína 
T.V.M. Fajardo et al.

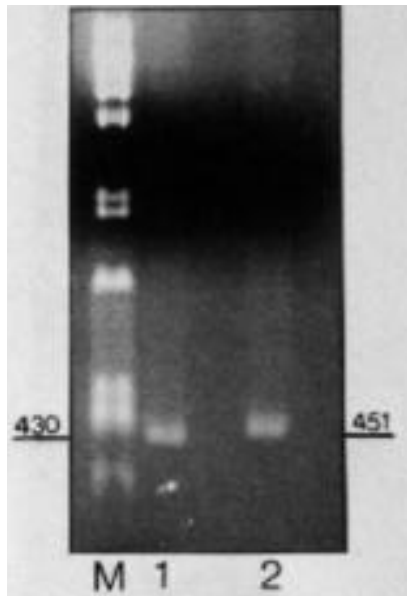

FIG. 1 - Análise eletroforética dos produtos da PCR a partir de RNA total extraído de videira (Vitis vinifera) cv. Pirovano 65 infetada com Grapevine virus A (GVA) em gel de agarose 1,5\%. (M) Marcador, DNA de fago $\lambda P s t I$, (1) fragmento de $430 \mathrm{pb}$ e (2) fragmento de 451 pb, obtidos, respectivamente, com os oligonucleotídeos C995/H587 e C1197/766.

capsidial do GVA-RS foi depositada no banco de dados GenBank com o código de acesso AF494187. Os resíduos de aminoácidos conservados RQ/FDF, identificados como es truturas de "ponte de sal", presentes em proteínas capsidiais de vírus filamentosos com ssRNA (Dolja et al., 1991; Minafra et al., 1994) encontram-se destacados (Figura 2).

As maiores identidades de nucleotídeos e aminoácidos deduzidos observadas foram de $91,4 \%$ e $95,4 \%$, respectivamente, verificadas entre o GVA-RS e um isolado italiano (Is151) de GVA (X75433) (Minafra et al., 1994; Minafra et al., 1997) (Tabela 1). Altas identidades de nucleotídeos (84,4 a 89,3\%) e de aminoácidos deduzidos $(84,8$ a $95,4 \%)$ também foram verificadas com outros cinco isolados de GVA, de diferentes origens geográficas (África do Sul, Israel e Japão) (Tabela 1).

A comparação da sequiência da proteína capsidial do GVA-RS com a de outras espécies do gênero Vitivirus [GVB, GVD e Heracleum latent virus (HLV)], demonstrou maiores identidades de nucleotídeos, $83,1 \%$ e $82,9 \%$, com HLV (X79270) e GVD (Y07764), respectivamente, seguida por GVB (AF438410, X75448, AB039842) (76\%). Em relação a homologia de aminoácidos deduzidos, a maior identidade foi verificada com GVD (75,9\%), seguida por GVB (56 a 56,5\%) e HLV $(56,1 \%)$.

\section{Análise do dendrograma}

Nos dendrogramas, obtidos através dos alinhamentos das seqüências de nucleotídeos e aminoácidos do gene da proteína capsidial de sete isolados de GVA e outras espécies do gênero Vitivirus (três de GVB e uma de GVD e outra de HLV), observa-se que o agrupamento mais próximo ocorreu sempre entre isolados da mesma espécie viral, corroborando os dados apresentados na Tabela 1. O isolado GVA-África do Sul 2 não se agrupa com os demais isolados de GVA, enquanto o isolado GVA-RS agrupa-se mais proximamente

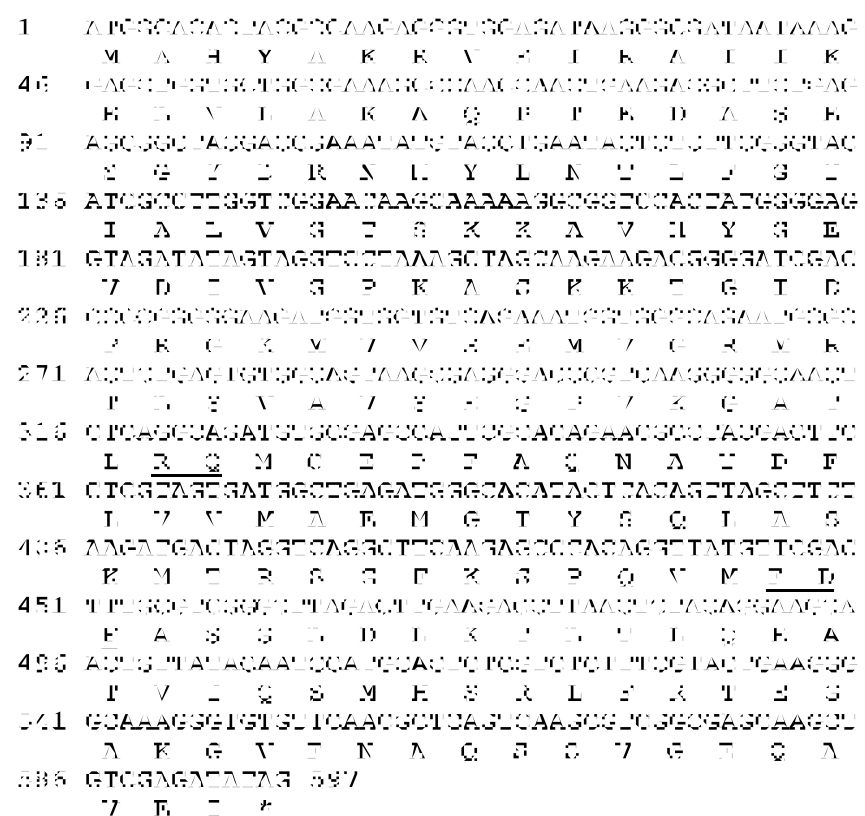

FIG. 2 - Sequiência de nucleotídeos (superior) e aminoácidos deduzidos (inferior) do gene da proteína capsidial do Grapevine virus A (GVA), isolado RS. Os nucleotídeos estão numerados a partir da extremidade 5' da fita viral e o asterisco indica o código de terminação. Esta sequiência foi depositada no GenBank com o código de acesso AF494187. Os resíduos conservados $\mathrm{RQ} / \mathrm{FDF}$ encontram-se sublinhados.

ao isolado GVA-Itália (Is151) (Figura 3) e, independente e intermediariamente, entre os isolados GVA-África do Sul 2 e o macro-grupo formado pelos isolados GVA-Itália, GVA-África do Sul 1, GVA-Japão, GVA-África do Sul 3 e GVA-Israel, considerando-se os dendogramas elaborados a partir das seqüências de nucleotídeos e aminoácidos (dado não mostrado), respectivamente.

\section{DISCUSSÃO}

Os resultados obtidos possibilitaram a detecção e a caracterização de um isolado local de GVA. As infecções do GVA-RS, observadas nas hospedeiras herbáceas, são basicamente similares aos relatos de Rosciglione et al. (1983), Agran et al. (1990) e Monette et al. (1990). Enquanto a reação ao GVA foi severa em N. occidentalis e $N$. megalosiphon, os sintomas observados em $C$. quinoa e $N$. benthamiana podem ser classificados como suaves. A infecção em $N$. occidentalis spp. obliqua apresentou-se latente, e $N$. cavicola e $C$. amaranticolor não foram infetadas. Considerando-se os sintomas obtidos neste trabalho em $N$. benthamiana, suave mosqueado foliar, em comparação com o nanismo e o clareamento de nervuras, evoluindo para clorose internerval com escurecimento da nervura principal, obtidos por Monette et al. (1990), é possível a existência de variações nas propriedades biológicas do isolado GVA-RS em relação a outros isolados. Agran et al. (1990) também mencionam a ocorrência de diferenças biológicas entre um isolado de GVA 
Deteç̧ão e caracterização do gene da proteína capsidial de um...

TABELA 1 - Comparação (identidade em percentagem) das seqüências de nucleotídeos (abaixo da diagonal) e de aminoácidos deduzidos (acima da diagonal) do gene da proteína capsidial do Grapevine virus A, isolado RS, com seqüências de outros isolados do mesmo vírus*

\begin{tabular}{|c|c|c|c|c|c|c|c|}
\hline \multirow[b]{2}{*}{ Tsolado de GVA* } & \multicolumn{7}{|c|}{ 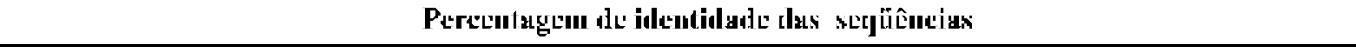 } \\
\hline & GVA -RS & $\begin{array}{l}\text { GVA - } \\
\text { ltália }\end{array}$ & $\begin{array}{c}\text { GVA - } \\
\text { Álrien da Sul } 1\end{array}$ & $\begin{array}{c}G V \Lambda- \\
\text { Álrical dn Sul } 2\end{array}$ & $\begin{array}{l}\text { GVA - } \\
\text { Israel }\end{array}$ & $\begin{array}{l}\text { GVA - } \\
\text { Japtin }\end{array}$ & $\begin{array}{c}\text { GVA - } \\
\text { Árica do Sul } 3\end{array}$ \\
\hline GiVA - KS & - & 95,4 & 94,9 & 84,8 & 95,4 & 95,4 & $90: 4$ \\
\hline GiVA - lá́lics & 91,4 & - & 97,4 & 83,8 & 96,9 & 96,9 & 929 \\
\hline [iVA - África do Su] 1 & 89,3 & 91,8 & - & 84,3 & 97,4 & 98,4 & 94,4 \\
\hline GiVA - Álïica do Ŝ̉ul 2 & 87,8 & 82,2 & 81,9 & & $8,3,8$ & 84.3 & 81,8 \\
\hline GVA Isacl & 85,7 & 81,9 & 86,7 & 77,2 & - & 97,9 & 94,4 \\
\hline GVA lapăo & 85,6 & 89,1 & 87,1 & 79,9 & 85,7 & - & 93,9 \\
\hline GVA - Álï̌a «lo Sul ? & 84,4 & 86,8 & 87,0 & 82,4 & 85,1 & 83,7 & - \\
\hline
\end{tabular}

*GVA-RS (AF494187, AAM14605); GVA-Itália (X75433, CAA53185); GVA-África do Sul 1 (AF441234, AAL76167); GVA-África do Sul 2 (AF441236, AAL76173); GVA-Israel (AF007415, AAB62939); GVA-Japão (AB039841, BAA92394) e GVA-África do Sul 3 (AF441235, AAL76170).

Os códigos de acesso no GenBank de nucleotídeos e aminoácidos estão indicados, respectivamente, entre parênteses.

da Tunísia e outros dois isolados italianos, todos com características fisico-químicas e sorológicas similares. Já Monette \& James (1990) relataram a existência de duas estirpes do GVA, biologicamente distintas, com base nos sintomas que induzem em $N$. benthamiana.

A detecção do GVA a partir de videiras infetadas é difícil. Os resultados podem ser inconsistentes mesmo utilizando-se técnicas de diagnóstico sensíveis, em virtude de o vírus encontrar-se irregularmente distribuído, atingir títulos muito baixos em tecidos infetados (floema), e sofrer variações sazonais. Assim, justificam-se os estudos relatados no presente trabalho, à semelhança de outros (Minafra et al.,1992; Minafra \& Hadidi, 1994), objetivando a detecção e a identificação do GVA em videiras de forma precisa e consistente. Não foi possível detectar o GVA, com "western blot", em videiras e hospedeiras herbáceas infetadas (dados não mostrados), atribuindo-se este fato à baixa concentração viral nas plantas analisadas e/ou a qualidade dos anti-soros utilizados. A detecção sorológica deste vírus, independentemente da hospedeira, foi possível somente com a utilização do ELISA.

Raspas de ramos, pecíolos e nervuras de folhas maduras, ou seja, tecidos ricos em floema, foram os tecidos vegetais utilizados para o diagnóstico de GVA em videiras, por ELISA, conduzida conforme Boscia et al. (1992) e por PCR, confirmando observações publicadas anteriormente (Rubinson et al., 1997).

Boscia et al. (1992), comparando sete isolados de GVA de diferentes origens geográficas, por ELISA e com anticorpos monoclonais, constataram a existência de pouca diferença sorológica entre populações deste vírus. No presente estudo, os três diferentes anti-soros utilizados reconheceram o antígeno do GVA local. Este fato não surpreende, uma vez que nossos clones de Vitis spp., assim como os isolados de GVA usados na obtenção dos anti-soros, têm como origem principal a Europa. Também Castrovilli \& Gallitelli (1985) não encontraram diferenças sorológicas e nos tamanhos do RNA viral e da proteína capsidial entre dois isolados de GVA, de diferentes regiões geográficas e com algumas propriedades biológicas distintas.

A massa molecular da proteína capsidial do GVA-RS, estimada em 21,6 kDa, é praticamente idêntica àquela calculada por Minafra et al. (1994) com base na sequência de aminoácidos deduzidos do gene da proteína capsidial, e muito próxima àquela de $22,5 \mathrm{kDa}$ determinada pela mobilidade eletroforética de preparações virais purificadas (Boscia et al., 1993).

Rubinson et al. (1997) concluem que embora menos sensíveis do que a PCR, os métodos sorológicos, como o ELISA, são mais adequados para procedimentos rotineiros de detecção de vírus, incluindo-se o GVA, assim como na indexagem viral em grande escala, pois tais métodos se utilizam de extratos brutos da planta.

Com a publicação de seqüências de nucleotídeos de vários vírus que infetam fruteiras temperadas, incluindo-se o GVA da videira (Minafra et al., 1994), é possível a detecção desses agentes por RT-PCR em suas respectivas hospedeiras naturais (Minafra \& Hadidi, 1994). A grande maioria destes vírus não infeta, ou o faz com grande dificuldade (ex. GVA), hospedeiras herbáceas alternativas, a partir de onde a detecção viral, bem como o estudo viral, são consideravelmente simplificados.

O sucesso da amplificação do RNA do GVA, a partir de extratos de ácidos nucléicos de videiras infetadas, é dependente da remoção de inibidores (compostos polifenólicos) que interferem com as reações de RT-PCR. Desta forma, o sucesso na RT-PCR, obtido neste trabalho e por Minafra et al. (1992), pode ser atribuído em grande parte à qualidade das preparações de RNA total de videira analisadas.

A detecção de GVA, GVB e Grapevine leafrollassociated virus 3 (GLRaV-3) tem sido insatisfatória em virtude 
T.V.M. Fajardo et al.

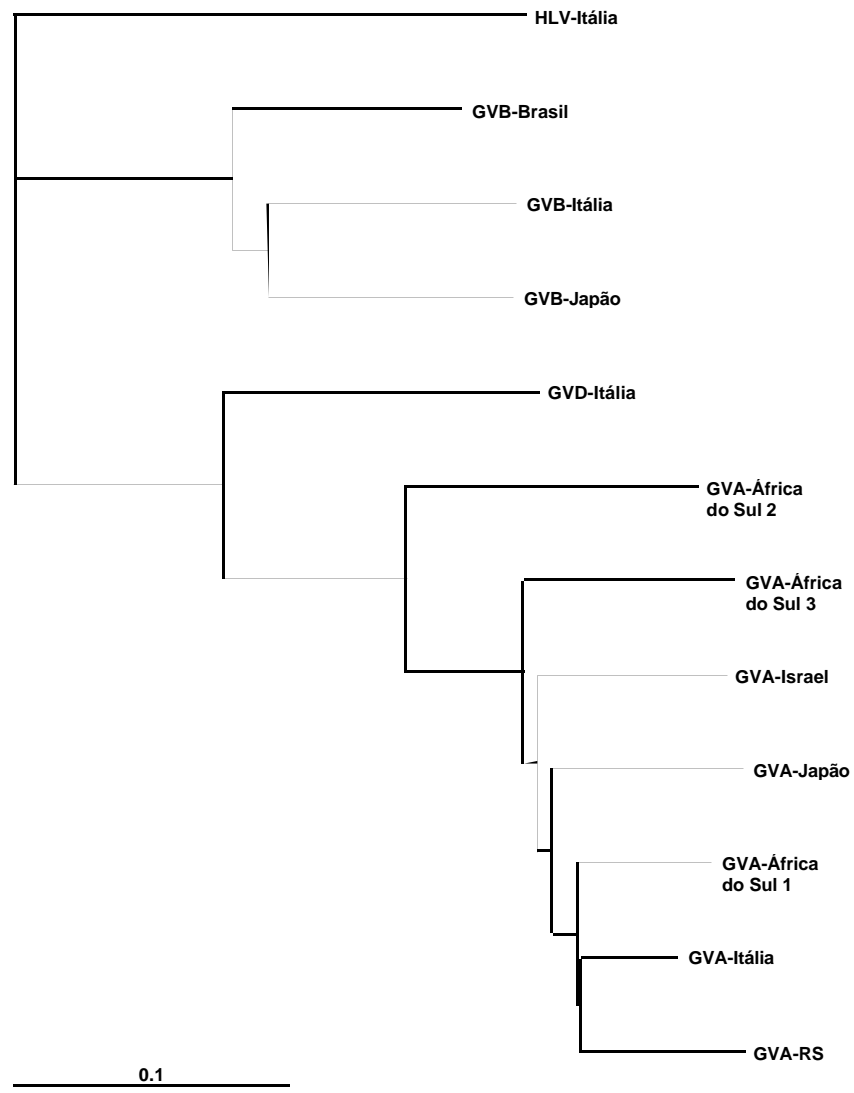

FIG. 3 - Dendrograma (TreeView 1.5) obtido através do alinhamento (Clustal X) das sequiências de nucleotídeos do gene da proteína capsidial de diferentes isolados de vírus do gênero Vitivirus. Acessos: AF494187 (GVA-RS); X75433(GVA-Itália); AF441234 (GVA-África do Sul 1); AF441236 (GVA-África do Sul 2); AF007415 (GVA-Israel); AB039841 (GVA-Japão); AF441235 (GVA-África do Sul 3); X79270 (HLV-Itália); Y07764 (GVD-Itália); X75448 (GVB-Itália); AF438410 (GVB-Brasil); AB039842 (GVB-Japão). A barra significa 0,1 substituições de nucleotídeos por sítio.

dos tecidos de videiras infetadas apresentarem baixo título viral e por serem ricos em compostos polifenólicos. Minafra \& Hadidi (1994) obtiveram sucesso na detecção do GVA, a partir de preparações de ácidos nucléicos totais de videiras e de cochonilhas virulíferas. Com IC-RT-PCR, GVA foi detectado em tecidos jovens de videira, onde o título viral é geralmente inferior ao limite de detecção do ELISA (Chevalier et al., 1995). Desta forma, aumenta-se o espectro dos métodos disponíveis para a precisa detecção do GVA.

A análise filogenética dos dados obtidos permite concluir que as proteínas capsidiais dos sete isolados de GVA comparados são muito próximas. A variabilidade é tão limitada que é admissível supor uma origem de dispersão comum ou muito próxima. A exceção é o isolado GVA-África do Sul 2, com 15,2\% de divergência de aminoácidos deduzidos em relação ao GVA-RS (Tabela 1). É possível que esta variabilidade, bem como outras afins, possa ser decorrente da adaptação do isolado viral a situações de ambiente, área geográfica, cultivares de videira ou vetores (cochonilhas) específicas e particulares.

A alta homologia detectada entre o isolado italiano Is151 e o GVA-RS fortemente sugere que o isolado GVA-RS possa ter chegado ao Brasil a partir de material propagativo ou mudas de videira originários da Itália. No passado, verificou-se a introdução, por imigrantes italianos assentados na Serra Gaúcha, de material propagativo de videira, sem atender a princípios de sanidade vegetal. Atualmente, a importação de mudas de videira da Itália, bem como de outros países, é mais criteriosa, embora a grande quantidade de mudas que entra no país seja motivo de preocupação.

A homologia observada entre os diferentes isolados de GVA e, em particular entre o GVA-RS e o isolado Is151, é similar à verificada por Rubinson et al. (1997). Estes autores, ao compararem os isolados PA3 e Is151 (Minafra et al., 1994) de GVA, observaram $88 \%$ e $97 \%$ de identidade entre as sequências de nucleotídeos e de aminoácidos deduzidos do gene da proteína capsidial, respectivamente.

A anális e filogenética envolveu somente os genes da proteína capsidial de GVA, GVB, GVD e HLV, uma vez que, atualmente, está estabelecida e aceita, a posição taxonômica destes vírus no gênero Vitivirus (Martelli et al., 1997; Regenmortel, 2000). Adicionalmente observamos baixas homologias, $48-49 \%$ e $47 \%$ de identidade de aminoácidos deduzidos, respectivamente, entre o GVA-RS e Apple chlorotic leaf spot virus (ACLSV) e Grapevine berry inner necrosis virus (GINV), espécies do gênero Trichovirus, onde se agrupava o GVA até seu estabelecimento no atual gênero (Regenmortel, 2000). A homologia registrada entre o GVA-RS e isolados de ACLSV é semelhante àquela relatada por Minafra et al. (1994).

Embora se constate homologias de $56-57 \%$ entre as proteínas capsidiais de isolados de GVA e GVB, e de cerca de $75 \%$ entre GVA e GVD, neste trabalho e em outros (Choueiri et al., 1997; Nickel et al., 2002), estas similaridades não se refletem nas propriedades sorológicas e moleculares desses vírus, cujos anti-soros e sondas moleculares não apresentam reações cruzadas ou, se presentes, são fracas (Boscia et al., 1993; Martelli et al., 1997). Entretanto, reações heterólogas ocorrem em procedimentos desnaturantes, que expoem e tornam acessíveis os poucos determinantes antigênicos compartilhados por estes vírus (Goszczynski et al., 1996). Nossos resultados de ausência de reações heterólogas, em ELISA, envolvendo a utilização de anti-soros contra GVA, GVB e GVD corroboram as observações de que diferenças sorológicas existem em nível de espécies (Martelli et al., 1997). Os resultados de homologia verificados entre estes três vírus do gênero Vitivirus (GVA, GVB e GVC), com base nas identidades de nucleotídeos e de aminoácidos do gene da proteína capsidial, também servem para fundamentar os relaciomentos sorológico e de parentesco verificados entre estes vírus, conforme estabelecido por Martelli et al. (1997).

\section{REFERÊNCIAS BIBLIOGRÁFICAS}

AGRAN, M.K., TERLIZZI, B.D., BOSCIA, D., MINAFRA, A., SAVINO, V., MARTELLI, G.P. \& ASKRI, F. Occurrence of Grapevine 
Detecção e caracterização do gene da proteína capsidial de um...

virus $A$ (GVA) and other closteroviruses in Tunisian grapevines affected by leafroll disease. Vitis 29:43-48. 1990.

BOSCIA, D., ASLOUJ, E., ELICIO, V., SAVINO, V., CASTELlANO, M.A. \& MARTELli, G.P. Production, characterization and use of monoclonal antibodies to Grapevine virus A. Archives of Virology 127:185-194. 1992.

BOSCIA, D., SAVINO, V., MINAFRA, A., NAMBA. S., ELICIO, V., CASTELLANO, M.A., GONSALVES, D. \& MARTELLI, G.P. Properties of a filamentous virus isolated from grapevines affected by corky bark. Archives of Virology 130:109-120. 1993.

CASTROVILLI, S. \& GALLITELLI, D. A comparison of two isolates of Grapevine virus A. Phytopathologia Mediterranea 24:219-220. 1985.

CHEVALIER, S., GREIF, C., CLAUZEL, J.M., WALTER, B. \& FRITSCH, C. Use of an immunocapture-polymerase chain reaction procedure for the detection of Grapevine virus A in Kober stem grooving-infected grapevines. Journal of Phytopathology 143:369373. 1995.

CHOUEIRI, E., ABOU-GHANEM, N. \& BOSCIA, D. Grapevine virus $A$ and Grapevine virus $D$ are serologically distantly related. Vitis 36:39-41. 1997.

CLARK, M.F. \& ADAMS, A.N. Characteristics of the microplate method of enzyme linked immunosorbent assay for the detection of plant viruses. Journal of General Virology 34:475-483. 1977.

DOLJA, V.V., BOYKO, V.P., AGRANOVSKY, A.A. \& KOONIN, E.V. Phylogeny of capsid proteins of rod-shaped and filamentous RNA plant virus: two families with distinct patterns of sequence and probably structure conservation. Virology 184:79-86. 1991.

FAJARDO, T.V.M., KUHN, G.B., EIRAS, M. \& NICKEL, O. Caracterização parcial de um isolado do Grapevine fanleaf virus. Fitopatologia Brasileira 25:505-511. 2000.

GARAU, R., PROTA, V.A., PIREDDA, R., BOSCIA, D. \& PROTA, $\mathrm{U}$. On the possible relationship between Kober stem grooving and Grapevine virus A. Vitis 33:161-163. 1994.

GOSZCZYNSKI, D.E., KASDORF, G.G.F. \& PIETERSEN, G. Western blots reveal that Grapevine viruses $A$ and $B$ are serologically related. Journal of Phytopathology 144:581-583. 1996.

KUHN, G.B., FAJARDO, T.V.M. \& NICKEL, O. Viroses da videira identificadas na Região do Submédio São Francisco no polo vitícola Petrolina/Juazeiro. Fitopatologia Brasileira 25:442. 2000. (Resumo).

KUHN, G.B., FAJARDO, T.V.M. \& VANNI, M.F. Incidência de viroses em videiras americanas no Rio Grande do Sul. Fitopatologia Brasileira 27:S206-S207. 2002. (Resumo).

KUNIYUKI, H. Vitivirus - Biological aspects. Virus Reviews \& Research 06:33. 2001. (Abstract).

KUNIYUKI, H., REZENDE, J.A.M., YUKI, V.A. \& BETTI, J.A. Detecção serológica do vírus A da videira em vinhedos do Estado de São Paulo. Summa Phytopathologica 27:116-117. 2001. (Resumo). LA NOTTE, P., BUZKAN, N., CHOUEIRI, E., MINAFRA, A. \&
MARTELLI, G.P. Acquisition and transmission of Grapevine virus $A$ by the mealybug Pseudococcus longispinus. Journal of Plant Pathology 79:79-85. 1997.

MACKENZIE, D.J., MCLEAN, M.A., MUKERJI, S. \& GREEN, M. Improved RNA extraction from woody plants for the detection of viral pathogens by reverse transcription-polymerase chain reaction. Plant Disease 81:222-226. 1997.

MARTELLI, G.P., MINAFRA, A. \& SALDARELLI, P. Vitivirus, a new genus of plant viruses. Archives of Virology 142:1929-1932. 1997. MINAFRA, A., HADIDI, A. \& MARTELLI, G.P. Detection of grapevine closterovirus A in infected grapevine tissue by reverse transcription-polymerase chain reaction. Vitis 31:221-227. 1992.

MINAFRA, A. \& HADIDI, A. Sensitive detection of Grapevine virus $A, B$, or leafroll-associated III from viruliferous mealybugs and infected tissue by cDNA amplification. Journal of Virological Methods 47:175-188. 1994.

MINAFRA, A., SALDARELLI, P., GRIECO, F. \& MARTELLI, G.P. Nucleotide sequence of the 3' terminal region of the RNA of two filamentous grapevine viruses. Archives of Virology 137:249-261. 1994.

MINAFRA, A., SALDARELLI, P. \& MARTELLI, G.P. Grapevine virus $A$ : nucleotide sequence, genome organization, and relationships in the Trichovirus genus. Archives of Virology 142:417-423. 1997.

MONETTE, P.L., GODKIN, S.E. \& JAMES, D. Mechanical sap transmission of a closterovirus from in vitro shoot tip cultures of a leafroll-affected grapevine to Nicotiana benthamiana. Vitis 29:49-55. 1990.

MONETTE, P.L. \& JAMES, D. Detection of two strains of Grapevine virus A. Plant Disease 74:898-900. 1990.

NICKEL, O., FAJARDO, T.V.M., ARAGÃO, F.J.L., CHAGAS, C.M. \& KUHN, G.B. Detection and coat protein gene characterization of an isolate of Grapevine virus B from corky bark-affected grapevines in Southern Brazil. Fitopatologia Brasileira 27:279-284. 2002.

PAGE, R.D.M. TreeView: An application to display phylogenetic trees on personal computers. Computer Applications in the Biosciences 12:357-358. 1996.

REGENMORTEL, M.H.V., FAUQUET, C.M., BISHOP, D.H.L., CARSTENS, E.B., ESTES, M.K., LEMON, S.M. MANILOFF, J., MAYO, M.A., McGEOCH, D.J., PRINGLE, C.R. \& WICKNER. R.B. (Eds.). Virus Taxonomy - Classification and Nomenclature of Viruses. Genus Vitivirus. San Diego. Academic Press. 2000. pp. 960964.

ROSCIGLIONE, B., CASTELLANO, M.A., MARTELLI, G.P., SAVINO, V. \& CANNIZZARO, G. Mealybug transmission of Grapevine virus A. Vitis 22:331-347. 1983.

RUBINSON, E., GALIAKPAROV, N., RADIAN, S., SELA, I., TANNE, E. \& GAFNY, R. Serological detection of Grapevine virus $A$ using antiserum to a nonstructural protein, the putative movement protein. Phytopathology 87:1041-1045. 1997. 